\title{
IMPLEMENTASI KURIKULUM TERSEMBUNYI (HIDDEN CURRICULUM) DALAM PEMBENTUKAN KARAKTER MELALUI PEMBELAJARAN DARING PADA MASA PANDEMI COVID-19
}

\author{
Mumu ${ }^{1}$, Adang Danial ${ }^{2}$ \\ Pendidikan Masyarakat, FKIP, Universitas Siliwangi, Indonesia \\ mumu@unsil.ac.id
}

\begin{abstract}
Abstrak
Sejak merebaknya Covid-19, pemerintah melalui Kemendikbud mengeluarkan SE No. 36962/MPK.A/HK/2020 yang memutuskan untuk memindahkan proses pembelajaran tatap muka menjadi pembelajaran secara daring yang diberlakukan di seluruh tingkatan satuan pendidikan. Namun masa pandemi covid-19 ini, pembelajaran daring menjadi persoalan kompleks karena guru secara fisik tidak bisa langsung interaktif dengan peserta didik, sehingga guru dituntut mencari bentuk pembelajaran daring untuk melaksanakan kurikulum formalnya dan sekaligus mengimplementasikan kurikulum tersembunyi tanpa mengurangi perannya dalam membangun karakter peserta didik. Penelitian ini menggunakan pendekatan kualitatif dengan metode deskriptif dan teknik pengumpulan data menggunakan teknik wawancara, observasi dan dokumentasi. Analisis data dilakukan terhadap implementasi kurikulum tersembunyi melalui pembelajaran daring pada tahap kegiatan pendahuluan pembelajaran, kegiatan inti pembelajaran, dan kegiatan penutup pembelajaran. Berdasarkan hasil penelitian, pembentukan karakter dalam pembelajaran daring pada kegiatan pendahuluan pembelajaran, para guru SDN Mugarsari telah menanamkan nilai-nilai karakter religius, disiplin, sopan, peduli sosial, dan partisipatif. Pada kegiatan inti pembelajaran, guru telah menanamkan nilai-nilai karakter mandiri, kerjasama, peduli lingkungan, dan percaya diri. Sedangkan pada kegiatan penutup pembelajaran, guru telah menanamkan nilai-nilai karakter berfikir kritis, jujur, tanggung jawab, dan religius.

Kata Kunci: Pandemi covid-19, pembelajaran daring, kurikulum tersembunyi, karakter peserta didik.
\end{abstract}

\begin{abstract}
Since the outbreak of Covid-19, the government through the Ministry of Education and Culture issued SE No. 36962/MPK.A/HK/2020 which decided to move the face-to-face learning process to online learning which was enforced at all levels of education units. However, during this COVID-19 pandemic, online learning is a complex problem because teachers cannot physically interact directly with students, so teachers are required to find forms of online learning to implement the formal curriculum and at the same time implement a hidden curriculum without reducing its role in building the character of students. This study uses a qualitative approach with descriptive methods and data collection techniques using interview, observation and documentation techniques. Data analysis was carried out on the implementation of the hidden curriculum through online learning at the stage of preliminary learning activities, core learning activities, and closing activities. Based on the results of the study, character building in online learning in preliminary learning activities, the teachers of SDN Mugarsari have instilled the values of religious character, discipline, politeness, social care, and participation. In the core learning activities, the teacher has instilled the values of independent character, cooperation, caring for the environment, and self-confidence. While in the closing activity of learning, the teacher has instilled the character values of critical thinking, honesty, responsibility, and religion.

Keywords: Covid-19 pandemic, online learning, hidden curriculum, student character.
\end{abstract}

\section{PENDAHULUAN}

Kurikulum memiliki posisi sangat penting dalam pendidikan baik kurikulum tertulis (written curriculum) maupun kurikulum tersembunyi (hidden curriculum) yang harus direalisasikan dalam pelaksanaan pembelajaran di berbagai satuan pendidikan. Proses pembelajaran yang dilakukan selama ini lebih mengacu pada kurikulum formal yang belum sepenuhnya memenuhi kebutuhan siswa untuk mendapatkan pengalaman yang 
berhubungan dengan penanaman nilai atau karakter. Karenanya, diperlukan secara optimal penerapan hidden curriculum yang secara teoritis sangat rasional memengaruhi peserta didik dalam mengenali dengan baik tentang lingkungan sekolah, suasana kelas, bahkan pada kebijakan dan manajemen sekolah secara luas baik dalam hubungan vertikal maupun horizontal (Dakir, 2010).

Hidden curriculum mempunyai pengaruh yang cukup besar terhadap internalisasi nilai dan karakter di sekolah dasar. Menurut Gattron dalam Caswita (2013:46), hidden curriculum adalah kurikulum yang tidak menjadi bagian yang harus dipelajari, yang digambarkan sebagai aspek yang ada di sekolah diluar kurikulum tertulis, tetapi mampu memberikan pengaruh dalam perubahan nilai, persepsi, serta perilaku peserta didik dalam mematuhi peraturan-peraturan sekolah, melaksanakan aturan atau acara keagamaan dan mematuhi peraturan-peraturan lainnya.

Selama ini guru hanya terpaku pada pedoman kurikulum yang telah ditetapkan oleh pengambil kebijakan (formal kurikulum), dan kurang memanfaatkan faktor lain diluar yang telah ditetapkan (hidden curriculum). Kebanyakan guru tidak mengetahui bahwa hidden curriculum sangat penting dilaksanakan di dalam pembelajaran, mereka hanya memperhatikan core curriculum (kurikulum inti) saja, padahal pada kenyataannya hidden curriculum mempunyai dampak postif di dalam pembelajaran (Caswita, 2013:8). Dampak pelaksanaan hidden curriculum antara lain terbentuknya pembiasaan positif pada diri peserta didik yang terpancar melalui karakter yang religius, disiplin, budaya bersih, sopan santun, serta saling tolong menolong sesama teman (Suryaningtyas, 2014:6-9).

Sekarang ini anak-anak sangat mudah mengambil dan menyerap informasi tentang pengetahuan, namun tidak jarang karena begitu asyik bermain gadget rentan terbangun pola pikir instan, individualistis, tidak mandiri, dan tidak respek terhadap keberagaman. Padahal, menjadi pribadi berkarakter mandiri, toleran, bertanggungjawab, bekerja keras, dan cerdas, merupakan kunci sukses menghadapi Revolusi Industri 4.0. Pendidikan karakter bagi peserta didik perlu diarahkan pada konsep pembelajaran untuk mengasah kegiatan bernalar dan berargumentasi, yang mana menjadi pondasi terbangunnya kecerdasan, sikap mandiri dan tidak anti keberagaman. Namun faktanya, hal-hal tersebut cenderung tidak menjadi fokus utama pendidikan di era informasi sekarang ini, karena kemampuan bernalar kritis, memecahkan masalah, dan rekonsiliasi permasalahan peserta didik menjadi minim. Peserta didik tidak sekadar bisa menghafal materi tanpa memiliki kecakapan karakter literer yang butuh penalaran mencakup kegiatan mencerna, menganalisis, dan menyampaikan kembali dengan baik. Ini merupakan di antara tantangan yang perlu dijadikan fokus pendidikan karakter saat ini.

Pelaksanaan pembelajaran daring di lapangan bukan tanpa masalah baik kaitannya dengan proses maupun hasil yang ingin dicapai dalam pembelajaran. Permasalahan yang muncul sebagaimana dikemukakan Saepuloh (2020), keberadaan guru tidak bisa hilang atau digantikan dengan internet begitu saja meskipun pekerjaan memberikan materi pembelajaran bisa diganti dengan teknologi, namun pendekatan batin dan pembentukan karakter serta pembiasaan spiritual oleh guru tak bisa tergantikan. Bahkan menurut Sri Rahayu (2020), dengan pembelajaran daring peran guru relatif terbatas pada menyiapkan materi pembelajaran, mengajarkan dan mengevaluasi pembelajaran saja, sementara tugastugas membentuk karakter peserta didik di gantikan oleh orang tua dalam membimbing keteraturan anak, kedisiplinan belajar, bahkan menjadi fasilitator yang baik bagi anaknya dalam belajar di rumah. Demikian juga pendapat Syamsul Arifin (2020), bahwa pembelajaran daring tidak bisa optimal dalam memfasilitasi terwujudnya salah satu aspek penting pendidikan, yaitu pembentukan sikap, lebih-lebih untuk level tinggi seperti yang disebut dalam teori klasik pendidikan dari Benjamin S. Bloom dengan characterization. 
Sejak merebaknya Covid-19 di Indonesia, pemerintah telah mengeluarkan peraturan untuk dunia pendidikan. Pemerintah melalui Mendikbud, memutuskan untuk memindahkan proses pembelajaran tatap muka menjadi pembelajaran secara daring diumumkan melalui S.E. Nomor 36962/MPK.A/HK/2020. Dengan demikian pembelajaran di rumah secara daring diberlakukan pada seluruh tingkatan pendidikan. Pemberlakuan peraturan tersebut mewajibkan peserta didik tinggal di rumah dan melakukan pembelajaran daring. Setiap hari, peserta didik mengerjakan tugas-tugas yang diberikan oleh guru, yang secara teknis guru hanya menyiapkan materi yang dilengkapi dengan perintah belajar dan latihan soal-soal secara mandiri.

Namun masa kenormalan baru covid-19 ini, pembelajaran yang dilakukan melalui daring atau online menjadi suatu persoalan yang kompleks, karena bagaimanapun juga guru yang hebat dengan karakter yang baik akan mengalami kesulitan ketika mentranmisikan nilai- nilai karakter tersebut diekspresikan melalui berbagai bentuk prilaku gurunya secara langsung di hadapan peserta didik. Guru melalui pembelajaran daring, secara fisik tidak bisa berhubungan langsung dengan para peserta didiknya, sehingga guru perlu mencari bentuk pembelajaran daring untuk melaksanakan kurikulum formalnya yang sekaligus mengimplementasikan kurikulum tersembunyi dengan baik tanpa mengurangi perannya dalam membangun karakter peserta didik.

Adapun tujuan penelitian ini adalah untuk mengetahui bagaimanakah implementasi kurikulum tersembunyi (hidden curriculum) yang dilakukan para guru dalam pembentukan karakter peserta didik melalui pembelajaran daring pada masa pandemi covid-2019 di SDN Mugarsari, Kota Tasikamalaya.

\section{KAJIAN TEORI}

\section{Konsep Dasar Kurikulum Tersembunyi}

Istilah kurikulum digunakan pertama kali pada dunia olahraga. Secara etimologis curriculum berasal dari bahasa Latin. "Curriculum" berarti "a running course, or race course, especially a chariat race course" dan dalam bahasa Perancis "course" yang artinya "to run, berlari" (IKIP Bandung, 1994:139). Jadi istilah kurikulum pada zaman romawi mengandung pengertian sebagai suatu jarak yang harus ditempuh oleh pelari dari garis start sampai garis finish. Kemudian istilah itu digunakan dalam bidang pendidikan yakni sejumlah "course" atau mata pelajaran yang harus ditempuh untuk mencapai suatu ijazah.

Dalam Undang-undang Republik Indonesia Nomor 20 tahun 2003 tentang Sistem Pendidikan Nasional, kurikulum adalah "seperangkat rencana dan peraturan mengenai tujuan, isi dan bahan pelajaran serta cara yang digunakan sebagai pedoman penyelenggara kegiatan pembelajaran untuk mencapai tujuan tertentu". Pengertian tersebut sejalan dengan pendapat Michaels, Grossman dan Scott sebagaimana dikutip oleh Toenlie: "The planned curriculum is defined as broad goals and spesific objectives, content, learning activities, use of instructional media, teaching strategises, and evaluation stated, planned and carried out by school personal".

Dari beberapa pendapat tentang kurikulum, maka kurikulum diartikan sebagai suatu program pendidikan yang berisi berbagai bahan ajar dan pengalaman belajar yang diprogramkan, direncanakan dan dirancangkan secara sistematik atas dasar norma yang berlaku yang dijadikan pedoman dalam proses pembelajaran bagi tenaga kependidikan dan peserta didik untuk mencapai tujuan pendidikan. Kurikulum mencakup pengertian yang sangat luas meliputi: kurikulum potensial, kurikulum aktual, dan kurikulum tersembunyi (hidden curriculum). Kurikulum potensial atau kurikulum ideal adalah suatu rencana atau program tertulis, yang merupakan pedoman bagi guru dalam melaksanakan kegiatan belajar-mengajar di sekolah. Setiap guru seharusnya dapat melaksanakan kegiatan sesuai 
dengan tuntutan kurikulum karena kurikulum ideal merupakan pedoman bagi guru, dan kurikulum dinamakan kurikulum formal atau kurikulum tertulis (written curriculum). Kurikulum aktual (actual curriculum) adalah kurikulum yang secara rill dapat dilaksanakan oleh guru sesuai dengan keadaan dan kondisi yang ada. Sedangkan kurikulum tersembunyi (hidden curriculum) adalah kegiatan yang terjadi di sekolah dan ikut memengaruhi perkembangan peserta didik, tetapi tidak diprogramkan dalam kurikulum potensial atau kurikuum ideal.

\section{Kurikulum Tersembunyi (Hidden Curriculum)}

Kurikulum tersembunyi (hidden curriculum) pada dasarnya adalah suatu proses pendidikan yang tidak terencanakan. Beberapa pendapat tentang kurikulum tersebunyi (hidden curriculum) seperti Valance dalam Dakir mengatakan bahwa hidden curriculum meliputi yang tidak dipelajari dari program sekolah yang non akademik. Sedangkan Kohelberg dalam Dakir (2019), mengatakan bahwa hidden curriculum sebagai hal yang berhubungan dengan pendidikan moral dan peran guru dalam mentransformasikan standar moral. Demikian juga, Dede Rosyada menyatakan bahwa hidden curriculum secara teoritik sangat rasional mempengaruhi siswa, baik menyangkut lingkungan sekolah, suasana kelas, pola interaksi guru dengan siswa di dalam kelas, bahkan pada kebijakan serta manajemen pengelolaan sekolah secara lebih luas dan perilaku dari semua komponen sekolah dalam hubungan interaksi vertikal dan horizontal.

Kurikulum tersembunyi sebagai suatu yang mengandung pendidikan dan pengajaran diwujudkan dalam bentuk pola-tindak orang-orang disekitar peserta didik yang bertujuan mempengaruhi tingkah lakunya, sehingga mereka mampu menyesuaikan diri sebaik mungkin dengan lingkungannya. Adanya perubahan tingkah laku yang terjadi di dalam diri peserta didik memungkinkannya untuk berfungsi secara sempurna dalam menjalani kehidupan di masyarakat. Hidden curriculum juga dapat menunjuk pada interaksi guru, peserta didik, struktur kelas, keseluruhan pola organisasi dan sebagainya dalam suatu hubungan sekolah. Pembelajaran sebagai hasil interaksi guru, siswa dan materi, seringkali tanpa disadari "dipelajari” siswa, walaupun itu tidak direncanakan, dan karena itu sering terabaikan sehingga luput dari perhatian guru. Hal inilah yang dikatakan hidden curriculum. Artinya kurikulum tersembunyi muncul sebagai hasil sampingan (side effects) dari interaksi antar siswa, guru dan materi serta lingkungan belajar.

\section{Pembentukan Karakter Peserta Didik}

Istilah karakter diambil dari bahasa Yunani "Charassian" yang berarti "to mark" atau menandai dan memfokuskan bagaimana mengaplikasikan nilai kebaikan dalam bentuk tindakan atau tingkah laku, sehingga orang yang tidak jujur, kejam, rakus dan perilaku jelek lainnya dikatakan orang berkarakter jelek. Sebaliknya, orang yang perilakunya sesuai dengan kaidah moral disebut dengan berkarakter mulia.

Pembentukan karakter mempunyai orientasi yang sama dengan pendidikan akhlak. Dalam implementasi pendidikan karakter atau pendidikan akhlak seorang pendidik yang paling bertanggung jawab dalam membimbing dan membina akhlak peserta didik sejak dini dengan memberikan keteladanan kepada mereka, sehingga mereka dapat membiasakan menghormati orangtuanya, keluarga, guru serta teman-temannya.

Proses pendidikan karakter merupakan keseluruhan proses pendidikan yang dialami peserta didik sebagai pengalaman pembentukan kepribadian melalui memahami dan mengalami sendiri nilai-nilai, keutamaan-keutamaan moral, nilai-nilai ideal agama, nilainilai moral. Thomas Lickona mengatakan bahwa pembentukan karakter merupakan usaha yang dilakukan dengan sengaja untuk mengembangkan kebajikan yang memampukan kita mengarah para kehidupan yang saling memenuhi dan membangun dunia yang lebih baik. 
Dalam upaya membentuk siswa berkarakter, maka guru perlu membimbing siswa dengan pendekatan pendidikan karakter. Kalau kita peduli untuk meningkatkan mutu lulusan SD, SMP, dan SMA, bahkan perguruan tinggi maka tanpa pendidikan karakter adalah usaha yang sia-sia. Pendidikan karakter sangatlah luas sehingga suatu yang tidak mungkin manakala ia hanya menjadi tanggung jawab guru. Oleh karena itu, timbul gagasan tentang pentingnya kurikulum tersembunyi (hidden curriculum) dalam pendidikan karakter yang tidak secara eksplisit ditulis dalam kurikulum. Pendapat ini beranggapan bahwa seluruh kegiatan guru, orang tua, masyarakat dan negara, diharapkan membantu dan melakukan pelayanan ekstra dalam membantu pencapaian tujuan pendidikan karakter. Sebuah sistem pendidikan yang berhasil dapat membentuk manusia-manusia berkarakter yang sangat diperlukan dalam mewujudkan sebuah negara yang terhormat sehingga karakter yang berkualitas perlu dibentuk dan dibina sejak di bangku sekolah.

\section{Indikator Pembentukan Karakter di Sekolah}

Penanaman nilai karakter dapat dilakukan melalui kegiatan pembelajaran dengan mengimplementasikan kurikulum tersembunyi. Kegiatan tersebut dilaksanakan agar siswa sekolah dasar mempraktikan nilai-nilai karakter yang ditargetkan teraktualkan melalui kegiatan perencanaan, pelaksanaan, dan evaluasi (Muchlas Samami dan Hariyanto 2013). Nilai-nilai pendidikan karakter menurut Kementrian Pendidikan dan Kebudayaan, sebagai berikut: (1) Religius, yaitu sikap ketaatan dan kepatuhan terhadap agama yang dianutnya serta memiliki toleransi terhadap agama lain; (2) Jujur, yaitu perilaku yang didasarkan pada upaya menjadikan dirinya sebagai orang yang selalu dapat dipercaya dalam perkataan, tindakan, dan pekerjaan; (3) Toleransi, yaitu sikap dan tindakan yang menghargai perbedaan agama, suku, etnis, pendapat, sikap, dan tindakan orang lain yang berbeda dari dirinya; (4) Disiplin, yaitu tindakan yang menunjukkan perilaku tertib dan patuh terhadap peraturan dan norma yang berlaku; (5) Kerja keras, yaitu suatu perbuatan yang dilakukan dengan sungguh sungguh tanpa mengenal lelah; (6) Kreatif, yaitu selalu mencari alternatif penyelesaian suatu permasalahan dari berbagai sudut pandang. Ini dilakukan untuk mengembangkan tata cara atau pemahaman terhadap suatu masalah yang sudah ada terlebih dahulu melalui pendekatan sudut pandang yang baru; (7) Mandiri, yaitu sikap dan perilaku yang tidak mudah tergantung pada orang lain dalam menyelesaikan tugas-tugas tanpa mengandalkan orang lain untuk menyelesaikan tugasnya; (8) Demokratis, yaitu cara berpikir, bersikap, dan bertindak yang menilai sama hak dan kewajiban dirinya dan orang lain; (9) Rasa Ingin Tahu, yaitu sikap dan tindakan yang selalu berupaya untuk mengetahui lebih mendalam dan meluas dari sesuatu yang dipelajarinya, dilihat, dan didengar; (10) Semangat Kebangsaan, yaitu cara berpikir, bertindak, dan berwawasan yang menempatkan kepentingan bangsa dan negara di atas kepentingan diri dan kelompoknya; (11) Cinta Tanah Air, yaitu cara berpikir, bertindak, dan berwawasan yang menempatkan kepentingan bangsa dan negara di atas kepentingan diri dan kelompoknya; (12) Menghargai Prestasi, yaitu sikap dan tindakan yang mendorong dirinya untuk menghasilkan sesuatu yang berguna bagi masyarakat, dan mengakui, serta menghormati keberhasilan orang lain; (13) Bersahabat/Komunikatif, yaitu sikap dan tindakan yang mendorong dirinya untuk menghasilkan sesuatu yang berguna bagi masyarakat, dan mengakui, serta menghormati keberhasilan orang lain; (14) Cinta Damai, yaitu sikap dan tindakan yang mendorong dirinya untuk menghasilkan sesuatu yang berguna bagi masyarakat, dan mengakui, serta menghormati keberhasilan orang lain. Sikap dan tindakan yang mendorong dirinya untuk menghasilkan sesuatu yang berguna bagi masyarakat, dan mengakui, serta menghormati keberhasilan orang lain; (15) Gemar Membaca, yaitu kebiasaan menyediakan waktu untuk membaca berbagai bacaan yang memberikan kebajikan bagi dirinya; (16) Peduli Lingkungan, yaitu sikap dan tindakan yang 
selalu berupaya mencegah kerusakan pada lingkungan alam di sekitarnya, dan mengembangkan upaya-upaya untuk memperbaiki kerusakan alam yang sudah terjadi; (17) Peduli Sosial, yaitu sikap dan tindakan yang selalu ingin memberi bantuan pada orang lain dan masyarakat yang membutuhkan; dan (18) Tanggung Jawab, yaitu sikap dan perilaku seseorang untuk melaksanakan tugas dan kewajibannya, yang seharusnya dia lakukan, terhadap diri sendiri, masyarakat, lingkungan (alam, sosial dan budaya), negara dan Tuhan Yang Maha Esa.

\section{METODE PENELITIAN}

Pendekatan yag digunakan dalam penelitian ini adalah pendekatan kualitatif fenomenologik naturalistik yang bertujuan memahami dan menafsikan makna suatu peristiwa interkasi tingkah laku dengan mengkaji secara mendalam tentang penerapan kurikulum tersembunyi dalam pembentukan karakter peserta didik melalui pembelajaran daring pada masa pandemi covid-19 di SDN Mugarsari Kota Tasikamalaya.

Penelitian ini laksanakan di SDN Mugarsari Kota Tasikmalaya. Pengambilan subyek penelitian menggunakan teknik bola salju, yang menurut Agus Salim (2006:13) "sampel diambil dari informan kunci, kemudian ditambah dan diluaskan menurut informasi sampel pertama begitu seterusnya. Penentuan informan kunci tersebut dilakukan secara sengaja, selanjutnya jika dalam pengumpulan data sudah tidak lagi ditemukan variasi informasi, maka peneliti tidak perlu lagi mencari informan baru, karena proses pengumpulan informasi dianggap selesai.

Metode yang digunakan dalam penelitian ini adalah metode deskriptif, karena penelitian ini mengambil masalah berkenaan untuk menggambarkan suatu gejala, peristiwa, dan kejadian yang terjadi pada masa sekarang. Metode deskriptif merupakan kumpulan laporan-laporan data penelitian untuk menggambarkan penyajian selama penelitian di lapangan. Sedangkan untuk mengolah data penelitian, peneliti menggunakan teknik, yaitu wawancara mendalam (dept interview), observasi, dan dokumentasi.

Analisis data dalam penelitian ini dilakukan selama proses pengumpulan data, karena dalam penelitian kualitatif analisis data lebih difokuskan selama proses kegiatan di lapangan bersamaan dengan pengumpulan data, dan setelah selesai pengumpulan data dalam periode tertentu (Sugiyono, 2012:245). Adapun langkah-langkah yang ditempuh dalam dalam analisis data adalah koleksi data (data collection), penyederhanaan data (data reduction), penyajian data (data display), dan pengambilan kesimpulan dan verifikasi (conclusion; drawing/verivying).

\section{HASIL DAN PEMBAHASAN}

Sekolah Dasar Negeri Mugarsari yang berlokasi di Kelurahan Mugarsari merupakan hasil merger dari dua sekolah yaitu SDN 1 dan SDN 2 Sumelap, terhitung mulai 6 Juli 2015 melalui SK Walikota Tasikmalaya Nomor 421.2/Kep. 286- Disdik/2015 tertanggal 6 Juli 2015. Sekolah Dasar yang mampu mencetak lulusan-lulusan terbaik di Kota Tasikmalaya.

SDN Mugarsari merupakan salah satu sekolah yang menyelenggarakan program inklusif di Kota Tasikmalaya, yaitu sekolah yang menerima siswa yang memiliki kebutuhan khusus. SDN Mugarsari memiliki komitmen untuk selalu terus meningkatkan kualitas dan kompetensinya sehingga dapat menciptakan lingkungan belajar yang baik.

Terdapat 28 orang pengajar yang memiliki kompetensi yang mumpuni dengan kualifikasi minimal S-1. Berbagai kegiatan siswa baik akademik maupun non akademik telah diadakan demi menampung bakat, minat dan kreativitas siswa, seperti ekstrakulikuler keagamaan, olahraga dan kesenian. Saat ini, prestasi yang diraih oleh siswa SDN Mugarsari telah mencapai lebih dari 40 penghargaan prestasi dalam satu tahun terakhir, baik prestasi akademik maupun non akademik dan salah satu prestasi yang diraih diantaranya setingkat 
kota.

\section{Pembentukan karakter dalam kegiatan pendahuluan pembelajaran daring}

Berdasarkan hasil wawancara dengan para guru SDN Mugarsari, melalui pembelajaran daring khususnya dalam kegiatan pendahuluan pembelajaran, para guru melakukan berbagai upaya pembentukan karakter peserta didik melalui kegiatan kurikulum tersembunyi yang menunjang karakter religius, disiplin, santun, peduli, dan partisipatif. Oleh karena itu, kurikulum tersembunyi muatannya bukan sebagai bahan pelajaran, melainkan penekanan sebagai sebuah penanaman sikap, kebijakan, dan penataan lingkungan dengan kepentingan masing-masing.

Tabel 1. Bentuk Karakter Dalam Kegiatan Pendahuluan Pembelajaran Daring

\begin{tabular}{|c|c|c|}
\hline Aspek & Indikator & Sub-Indikator \\
\hline \multirow[t]{5}{*}{$\begin{array}{l}\text { Kegiatan } \\
\text { Pendahuluan } \\
\text { Pembelajaran }\end{array}$} & Religius & $\begin{array}{l}\text { 01. Menganjurkan membaca doa sebelum belajar } \\
\text { 02. Menganjurkan mendoakan siswa yang sakit } \\
\text { 03. Menganjurkan doa bagi siswa yang berhalangan hadir }\end{array}$ \\
\hline & Disiplin & $\begin{array}{l}\text { 04. Belajar daring tepat waktu } \\
\text { 05. Belajar daring sesuai dengan alokasi waktu } \\
\text { 06. }\end{array}$ \\
\hline & Sopan & $\begin{array}{l}\text { 07. Menyampaikan salam melalui pesan daring } \\
\text { 08. Menyapa siswa melalui pesan daring } \\
\text { 09. Menanyakan kabar melalui pesan daring }\end{array}$ \\
\hline & Peduli sosial & $\begin{array}{l}\text { 10. Menanyakan kesiapan untuk memulai belajar } \\
\text { 11. Mengecek keterlibatan siswa belajar } \\
\text { 12. Menanyakan ketidak hadiran siswa } \\
\text { 13. Membantu teman yang mengalami kesulitan belajar }\end{array}$ \\
\hline & Partisipatif & $\begin{array}{l}\text { 14. Memberikan kesempatan bertanya } \\
\text { 15. Memberikan kesempatan menjawab pertanyaan } \\
\text { 16. Memberikan kesempatan keterlibatan siswa belajar }\end{array}$ \\
\hline
\end{tabular}

\section{Pembentukan karakter dalam kegiatan inti pembelajaran daring}

Pembentukan karakter peserta didik yang terintegrasi dengan kegitan inti pembelajaran dapat diarahkan kepada pembentukan berbagai karakter, misalnya kemandirian, berfikir logis, kreatif, kerjasama, kerja keras, saling menghargai, peduli lingkungan, dan percaya diri.

\section{Tabel 2. Bentuk Karakter Dalam Kegiatan Inti Pembelajaran Daring}

\begin{tabular}{|l|l|l|}
\hline \multicolumn{1}{|c|}{ Aspek } & Indikator & \multicolumn{1}{c|}{ Sub-Indikator } \\
\hline Kegiatan Inti & Kreatif dan & 01. Memberikan hadiah terhadap suatu perilaku kreatif \\
Pembelajara & Mandiri & 02. Memberikan penghargaan terhadap karya kreatif siswa \\
& & 03. Menganjurkan siswa bekerja mandiri \\
& & 04. Mencoba kemampuan mengambil keputusan sendiri \\
& 05. Meningatkan tidak mudah terpengaruh oleh orang lain \\
& Berfikir & 06. Menyediakan kesempatan berbagai aktifitas belajar \\
\cline { 2 - 4 } & logis & 08. Mendorong siswa meningkatkan semangat belajar \\
& & 09. Menganjurkan siswa membiasakan berpikir secarabenar \\
& & 10. Mendorong siswa mencari jawaban atas masalah belajar \\
\hline
\end{tabular}




\begin{tabular}{|l|l|ll|}
\hline & $\begin{array}{l}\text { Kerjasama } \\
\text { dan Saling } \\
\text { Menghargai }\end{array}$ & $\begin{array}{l}\text { 11. } \\
\text { 12. Menganjurkan siswa berpartisipasi dalam diskusi }\end{array}$ & Menganjurkan bekerja sama sesama teman \\
& 14. & Menganjurkan menghargai pendapat teman saat diskusi \\
& 15. & Menganjurkan untuk menerima pendapat orang lain \\
& 16. & Menanjurkan memberi salam apabila saling bertemu \\
& Peduli & 17. & Menganjurkan jaga kebersihan rumah dan lingkungan \\
& Lingkungan & 18. Menganjurkan pembiasaan hemat energi \\
\hline Percaya diri & 19. Memberikan pujian atau membiasakan memuji siswa \\
& 20. Memberikan motivasi untuk berhasil belajar \\
& 21. Menganjurkan menyimpulkan materi pelajaran \\
\hline
\end{tabular}

\section{Pembentukan karakter dalam kegiatan penutup pembelajaran daring}

Pembentukan karakter peserta didik yang terintegrasi dengan kegitan tutup pembelajaran dapat diarahkan kepada pembentukan berbagai karakter, misalnya kritis, jujur, percaya diri, tanggung jawab, dan religius.

\section{Tabel 3. Bentuk Karakter Dalam Kegiatan Penutup Pembelajaran Daring}

\begin{tabular}{|c|c|c|}
\hline & \multicolumn{2}{|r|}{ Deskripsi } \\
\hline \multirow{11}{*}{$\begin{array}{l}\text { Kegiatan } \\
\text { Tutup } \\
\text { Pembelajaran }\end{array}$} & \multirow{3}{*}{$\begin{array}{r}\text { Berfikir } \\
\text { Kritis }\end{array}$} & 01. Mempersilahkan mengamati hasil belajar yang diperoleh \\
\hline & & 02. Menganjurkan mengatasi masalah individu/kelompok. \\
\hline & & 03. Memberikan kesempatan bertanya diakhir belajar \\
\hline & \multirow[t]{3}{*}{ Jujur } & 04. Mendorong untuk mematuhi perintah/petunjuk guru \\
\hline & & 05. Mengajak siswa selalu berkata dan bertingkah laku jujur \\
\hline & & 06. Menganjurkan siswa untuk mengerjakan tugas sendiri \\
\hline & Tanggung & 07. Mengingatkan untuk menyelesaikan tugas secara tuntas \\
\hline & Jawab & 08. Menganjurkan untuk mengerjakan tes secara individu \\
\hline & Religius & 09. Menganjurkan siswa membaca doa ketika selesai belajar \\
\hline & & 10. Memberikan pesan untuk selalu belajar dengan baik \\
\hline & & 11. Memberikan contoh teladan yang baik kepada siswa \\
\hline
\end{tabular}

\section{Analisis Hasil Penelitian}

Sebagaimana hasil penelitian yang peroleh di SDN Mugarsari Tamansari Kota Tasikmalaya, terkait dengan implementasi kurikulum tersembunyi (hidden curriculum) dalam pembentukan karakter peserta didik melalui pembelajaran daring pada masa pandemic covid-19, maka peneliti menganalisis sebagai berikut:

\section{Pembentukan karakter dalam kegiatan pendahuluan pembelajaran}

Dalam kegiatan pendahuluan pembelajaran, implementasi kurikulum tersembunyi (hidden curriculum) dalam pembentukan karakter peserta didik melalui pembelajaran daring pada masa pandemi covid-19 yang dilakukan para guru SDN Mugarsari, terbatas kepada pembentukan karakter-karakter tertentu yang memungkinkan bisa dilakukan oleh para guru, karena pembelajaran daring tidak semudah seperti yang dilakukan dalam pembelajaran luring atau tatap muka langsung melalui pelaksanaan kurikulum nyata di kelas. Adapun pembentukan karakter peserta didik melalui pembelajaran daring meliputi karakter religius, disiplin, sopan santun, peduli sosial, dan partisipatif.

Melalui pembelajaran daring, para guru SDN Mugarsari dalam membentuk karakter religius sudah membiasakan diri menyampaikan salam sapa kepada peserta didik sebelum kegiatan belajar dimulai baik secara lisan maupun tertulis yang terintegrasi dengan lembar 
pekerjaan atau tugas yang diberikan kepada peserta didik. Salam sapa yang dibiasakan guru tidak hanya saat kegiatan belajar saja, tetapi merupakan sesuatu yang dibiasakan dilakukan guru setiap berinteraksi dengan peserta didik kapanpun dan dimanapun termasuk di luar kegiatan belajar. Pembiasaan lain yang selalu dilakukan guru adalah menganjurkan kepada peserta didik untuk membiasakan diri membaca doa untuk mengawali dan mengakhiri pembelajaran yang dilakukan baik secara sendiri-sendiri maupun secara bersama-sama, termasuk mengajak kepada peserta didik untuk membiasakan diri selalu membantu dan memberikan doa-doa kebaikan kepada rekan-rekannya supaya dapat mengatasi masalahmasalah belajar yang dihadapinya, dan doa-doa kesembuhan apabila ada rekan-rekan lainnya yang sakit yang menyebabkan tidak bisa mengikuti kegiatan pembelajaran.

Pembentukan karakter peserta didik lainnya adalah karakter disiplin, di mana para guru SDN Mugarsari setiap memulai pembelajaran daring sudah membiasakan diri terlebih dahulu menyampaikan pesan kepada peserta didik bahwa belajar dilaksanakan tepat waktunya sebagaimana yang telah ditetapkan dalam jadwal pelajaran. Guru juga selalu menyampaikan informasi tentang alokasi waktu yang digunakan untuk melaksanakan kegiatan belajar yang lamanya sesuai dengan beban belajar yang diberlakukan bagi peserta didik di sekolah. Kemudian untuk lebih tertibnya peserta didik dalam mengikuti pembelajaran daring, guru selalu mengecek partisipasi dan keterlibatan peserta didik dalam melalui catatan harian tentang mereka. Demikian juga, para guru telah berusaha agar siswa mempunyai sikap dan perilaku yang selalu tertib dan patuh terhadap ketentuan dan peraturan.

Pembentukan karakter peserta didik lainnya adalah karakter sopan santun, di mana para guru SDN Mugarsari setiap berinteraksi dengan peserta didiknya terutama pada saat dimulai pembelajaran daring, melalui pesan lisan atau tertulis mereka selalu membiasakan diri menyapa peserta didik tentang kesiapan belajarnya dengan kata-kata yang sopan, bahkan selalu membiasakan diri menanyakan kabar tentang keberadaan mereka, tentang kegiatan belajarnya, kesehatannya, dan kadang-kadang menanyakan kabar tentang keluarganya dengan bijak.

Pembentukan karakter peserta didik lainnya adalah karakter sopan santun, di mana para guru SDN Mugarsari, ternyata para guru sebelum belajar daring dimulai sudah membiasakan diri menanyakan tentang kesiapan peserta didik. Guru memperhatikan keterlibatan dan partisipasi peserta didik dalam pembelajaran, karena dihawatirkan mungkin saja diantara mereka ada yang lupa terhadap jadwal belajar sehingga mereka tidak mengikuti kegiatan pembelajaran. Apabila ada diantara mereka tidak mengikuti pelajaran, para guru selalu menanyakan kenapa dan kesulitan apa sehingga menyebabkan tidak mengikuti pelajaran, bahkan guru selalu menganjurkan kepada peserta didik untuk membiasakan diri saling membantu apabila diantara teman-temannya ada yang mengalami kesulitan belajar.

Pembentukan karakter peserta didik lainnya adalah karakter partisipatif, di mana para guru SDN Mugarsari melalui pembelajaran daring mereka sudah membiaskan diri memberikan kesempatan bertanya kepada peserta didik hal-hal yang berhubungan dengan materi sebelum kegiatan belajar dimulai. Selain itu, juga guru memberikan kesempatan kepada peserta didik untuk menjawab pertanyaan yang disampaikan oleh guru atau sesama temannya sebelum kegiatan pembelajaran daring dimulai. Dari semua pembiasaan tersebut di atas yang dilakukan para guru SDN Mugarsari, merupakan upaya yang dilakukan dalam rangka membentuk berbagai karakter peserta didik melalui implementasi kurikulum tersembunyi melalui pembelajaran daring pada masa pandemi covid-19 yang dilakukan pada kegiatan pendahuluan pembelajaran. 


\section{Pembentukan karakter dalam kegiatan inti pembelajaran}

Dalam kegiatan inti pembelajaran daring, implementasi kurikulum tersembunyi (hidden curriculum) dalam pembentukan karakter peserta didik melalui pembelajaran daring pada masa pandemi covid-19 yang dilakukan para guru SDN Mugarsari, meliputi karakter kreatif dan mandiri, berfikir logis, kerjasama dan saling menghargai, peduli lingkungan, dan percaya diri. Dalam membentuk karakter kreatif bagi peserta didik, para guru SDN Mugarsari selalu menanamkan sikaf kretaivitas melalui pembentukan karakter kreatif peserta didiknya dengan berusaha memberikan perlakuan secara konsisten berupa penghargaan, pengakuan, pujian, akan karya kreatif mereka. Siswa yang secara konsisten mendapatkan pengakuan dan penghargaan yang proporsional akan hasil karyanya, utamanya yang bernilai kreatif, merasa mendapatkan tempat akan prestasinya, dan semua itu dapat menumbuhkan rasa percaya diri dan konsep diri yang positif. Demikian juga, para guru SDN Mugarsari dalam membentuk karakter mandiri selalu berusaha mengembangkan diri peserta didiknya pada saat menyelesaikan ulangan atau tugas individu. Pengembangan diri yang diberikan oleh guru berupa himbauan ketika peserta didik mengerjakan ulangan atau tugas individu, agar dikerjakan secara mandiri tanpa melihat pekerjaan teman lainnya, serta dapat mengkreasikannya ketika ulangan atau tugas selesai dikerjakan. Selain itu, para guru memberi kesempatan kepada peserta didik membiasakan diri untuk dapat menyelesaikan masalah sendiri secara mandiri dengan baik tanpa bantuan orang lain. Hal ini sesuai dengan program pengembangan diri yang dilaksanakan melalui pembentukan karakter yang diintegrasikan ke dalam pembelajaran sehari-hari di sekolah, termasuk membiasakan diri untuk mengambil keputusan sendiri dalam menyelesaikan masalah-masalah belajar.

Dalam membentuk karakter berfikir logis bagi peserta didik, para guru SDN Mugarsari menganjurkan kepada peserta didik untuk selalu meningkatkan semangat belajar, membiasakan berfikir secara benar dalam memahami materi pelajaran, serta berusaha untuk mencari jawaban sendiri atas masalah-masalah belajar yang dihadapinya, karena berfikir logis merupakan bentuk kemampuan berfikir peserta didik dalam memahami pelajaran secara benar.

Pembentukan karakter kerjasama bagi peserta didik, para guru SDN Mugarsari selalu berusaha menganjurkan peserta didiknya membiaskan diri berpartisipasi dalam diskusi, saling membantu sesama anggota kelompok dalam memecahkan masalah-masalah belajar, bahkan disarankan diantara sesama anggota kelompok bahkan teman-temannya untuk saling bekerja sama dengan berbagi pengetahuan. Selain itu, para guru SDN Mugarsari selalu menganjurkan peserta didiknya untuk selalu membiasakan diri berkerjasama dalam pembelajaran dengan sesama teman lainnya. Ketika belajar bersama atau diskusi kelompok mereka dianjurkan untuk saling menghargai dan menerima pendapat teman lainnya, menasihati mereka supaya tidak menganggap rendah orang lain, mengucapkan salam kepada teman lainnya apabila saling bertemu, dan menanjurkan mengucapkan dengan kata maaf apabila ada khilap terhadap teman lainnya, serta ucapan terima kasih kepada teman yang telah memberikan kebaikan kepada dirinya.

Dalam membentuk karakter peduli lingkunan bagi peserta didik, para guru SDN Mugarsari melalui pembelajaran daring para guru selalu memberikan teladan dan himbauan kepada peserta untuk menjadi pribadi yang bersih, rapi, ramah, dan mandiri. Peserta didik diharapkan menjadi pribadi yang bersih, rapi, ramah, dan mandiri melalui himbauan dan nasihat yang disampaikan para guru, misalnya membiasakan diri selalu membersihkan tempat belajar sendiri baik pada saat sebelum maupun setelah pembelajaran daring berlangsung, termasuk himbauan untuk selalu membiaskan diri memanfaatkan sarana dan prasarana pembelajaran secara efektif dan efisien. 
Pembentukan karakter percaya diri bagi peserta didik, para guru SDN Mugarsari mengasah kepercayaan diri peserta didik adalah dengan membiasakan memuji siswanya dan memberikan apresiasi pada setiap apa yang dilakukan oleh siswa, baik itu bagus ataupun masih kurang bagus. Apabila ada kritik yang ingin disampaikan, para guru memulainya dengan sebuah pujian yang ditambahkan dengan pengarahan dengan harapan kritik tersebut dapat lebih mudah diterima anak-anak, termasuk memberikan kata-kata motivasi dalam segala aspek, motivasi belajar atau motivasi lain yang bisa meningkatkan bakat mereka, sehingga mereka percaya jika mereka berani mencoba untuk menuai hasil yang positif.

Dari semua pembiasaan tersebut di atas yang dilakukan para guru SDN Mugarsari, merupakan upaya yang dilakukan dalam rangka membentuk berbagai karakter peserta didik melalui implementasi kurikulum tersembunyi melalui pembelajaran daring pada masa pandemi covid-19 yang dilakukan pada kegiatan inti pembelajaran.

\section{Pembentukan karakter dalam kegiatan penutup pembelajaran}

Dalam kegiatan tutup kegiatan pembelajaran daring, implementasi kurikulum tersembunyi (hidden curriculum) dalam pembentukan karakter peserta didik melalui pembelajaran daring pada masa pandemi covid-19 yang dilakukan para guru SDN Mugarsari, meliputi karakter berfikir logis, jujur, tanggung jawab, dan religius.

Pembentukan karakter berfikir logis bagi peserta didik, para guru SDN Mugarsari selalu memberikan kesempatan kepada mereka untuk mengkoreksi kembali hasil belajar yang diperolehnya. Guru ini banyak memberikan tugas berupa kasus yang harus mereka pecahkan baik secara individual ataupun kelompok, termasuk menyelesaikan soal diatas kertas. Selain itu, diskusi antar anak dapat menciptakan dialog antara mereka. Selain itu, para guru telah melakukan berbagai upaya untuk menenamkan karakter berfikir kritis terhadap para siswanya, meskipun mereka menerima dan menyerap materi pelajaran dalam pemahaman yang relatif berbeda-beda.

Dalam membentuk karakter jujur bagi peserta didik, guru-guru SDN Mugarsari selalu mengingatkan anak-anaknya untuk mematuhi dan melaksanakan perintah guru terkait pembelajaran daring. Anak-anak diharapkan tidak melakukan kecurangan dalam mengerjakan tugas atau ujian, karena tindakan tersebut memungkinkan guru akan memberikan hukuman dengan menegur siswa supaya dapat menimbulkan efek jera. Selain itu, para guru sudah berusaha membentuk mereka agar mempunyai sikap dan perilaku yang selalu dapat dipercaya dalam perkataan, tindakan, dan pekerjaan lain. Hal ini sudah sesuai dengan tujuan dari pendidikan karakter yang dicanangkan oleh pemerintah untuk menanamkan nilai karakter peserta didik.

Pembentukan karakter tangung jawab bagi peserta didik, para guru dalam implementasi karakter ini terlihat ketika peserta didik dapat diandalkan ketika mengerjakan tugas. Seperti halnya melaksanakan tugas sesuai dengan aturan atau kesepakatan, bekerjasama dengan kelompoknya, termasuk bertanggung jawab atas semua tindakan yang dilakukannya. Selain itu, mereka mengerjakan tugas dan latihan yang kemudian mengumpulkannya tepat waktu sesuai dengan aturan kesepakatan bersama. Guru yang menjadi contoh teladan bagi para siswanya, guru juga berperan untuk membiasakan kebiasaan siswa dalam hal melaksanakan tugas-tugasnya sesuai dengan aturan kesepakatan.

Dalam membentuk karakter religius bagi peserta didik, para guru SDN Mugarsari melalui pembelajaran daring selalu berusaha agar peserta didik memiliki sikap religius yaitu dengan rutin membacakan do'a baik secara sendiri maupun bersama sebelum dan sesudah pembelajaran daring dilaksanakan. Selain itu, para guru selalu menganjurkan kepada peserta didik untuk mengucapkan salam kepada para sebelum pulang sekolah, serta memberikan contoh teladan yang baik kepada semua peserta didik. Dari semua pembiasaan-pembiasaan tersebut di atas yang dilakukan para guru SDN Mugarsari, merupakan upaya yang dilakukan 
dalam rangka membentuk berbagai karakter peserta didik melalui implementasi kurikulum tersembunyi melalui pembelajaran daring pada masa pandemi covid-19 yang dilakukan pada kegiatan inti pembelajaran.

\section{SIMPULAN}

Berdasarkan hasil penelitian dan analisis data, penulis dapat menyimpulkan sebagai berikut:

a. Guru-guru SDN Mugarsari dalam mengimplementasikan kurikulum tersembunyi melalui kegiatan pendahuluan pembelajaran, telah membiasakan diri menanamkan nilai-nilai karakter religius, disiplin, sopan, peduli sosial, dan partisipatif, melalui pesan-pesan yang disampaikan bersamaan dalam petunjuk belajar daring.

b. Guru-guru SDN Mugarsari dalam mengimplementasikan kurikulum tersembunyi melalui kegiatan inti pembelajaran, telah membiasakan diri menanamkan nilai-nilai karakter mandiri, kerjasama, peduli lingkungan, dan percaya diri, melalui pesan-pesan yang disampaikan bersamaan dalam petunjuk belajar daring.

c. Guru-guru SDN Mugarsari dalam mengimplementasikan kurikulum tersembunyi melalui kegiatan pendahuluan pembelajaran, telah membiasakan diri menanamkan nilai-nilai karakter berfikir kritis, jujur, tanggung jawab, dan religius. melalui pesan-pesan yang disampaikan bersamaan dalam petunjuk belajar daring.

\section{SARAN}

a. Kesadaran peserta didik perlu ditingkatkan lagi dengan memotivasi mereka supaya lebih giat dalam mengikuti kegiatan pembelajaran daring yang telah direncanakan oleh pihak sekolah.

b. Kompetensi guru perlu ditingkatkan supaya kompetensi yang dimilikinya dapat mengopimalkan perannya sebagai pendidik dan pembimbing secara lebih kreatif yang selalu berusaha menerapkan berbagai strategi dalam melaksanakan tugas pembelajaran.

c. Melengkapi sarana dan prasarana sekolah agar pembelajaran daring dapat dilaksanakan sesuai dengan yang diharapkan terutama dalam menunjang keberhasilan pelaksanaan kurikulum tersembunyi (hidden curriculum) pada masa pandemi covid-19 ini.

\section{DAFTAR PUSTAKA}

Anissah Suryaningtyas. (2014). Nilai-Nilai Pendidikan Islam Dalam Kurikulum Tersembunyi (Hidden Curriculum) di SDIT Muhammadiyah Sinar Fajar (Skripsi). FAI Universitas Muhammadiyah Surakarta.

Caswita. (2019). The Hidden Curriculum : Studi Pembelajaran PAI di Sekolah. Yogyakarta: PT Leutikaprio.

Dakir. (2019). Perencanaan dan Pengembangan Kurikulum. Jakarta: PT Rineka Cipta.

Dede Rosyada. (2004). Demokratisasi Pengembangan Kurikulum di Sekolah (Jurnal).

Lickona, Thomas. (2017). Buku Pendidikan Karakter. Bandung: PT Nusa Media.

Muchlas Samami dan Hariyanto. (2013). Konsep dan Model Pendidikan Karakter, Bandung: Remaja Rosdakarya.

Kemendiknas. (2010). Pengembangan Pendidikan Budaya dan Karakter Bangsa: Pedoman Sekolah. Jakarta: Balitbang.

Lickona, Thomas. (2012). Mendidik Untuk Membentuk Karakter: Bagaimana Sekolah Dapat Memberikan Pendidikan Tentang Sikap Hormat Dan Tanggung Jawab. Terjemahan Juma Abdu Wamaungo. Jakarta: P.T. Bumi Aksara.

Sisdiknas. (2003). Tentang Undang-undang Sistem Pendidikan Nasional No. 20 Tahun 2003.

Sri Rahayu, dkk. (2020). Belajar Mandiri: Pembelajaran Daring di Tengah Pandemi Covid19. Sumatra Utara: Yayasan Kita Menulis. 
Sugiyono. (2012). Metode Penelitian Kuantitatif Kualitatif dan R\&D. Bandung: Alfabeta. Syamsul Arifin. (2020). Pembelajaran Daring sebagai Anomali. Surabaya: Koran Jawa Pos. Thomas Lickona, (2013), Educating for Character How Our Schools Can Teach Respet and Responsibility. Jakarta: Bumi Aksara, Terjemahan Juma Abdu Wamaungo.

Tim Dosen Pengelolaan Pendidikan. (1994). Pengelolaan Pendidikan. Jurusan Administrasi Pendidikan FIP IKIP Bandung. 